\title{
Infantile macrocephaly and multiple subcutaneous lipomas diagnosed with PTEN hamartoma tumor syndrome: A case report
}

\author{
YUKA YOTSUMOTO $^{1,2}$, ATSUKO HARADA ${ }^{2,3}$, JIRO TSUGAWA ${ }^{4}$, YOSHIHIRO IKURA ${ }^{5}$, \\ HIDETSUNA UTSUNOMIYA $^{6}$, SATOKO MIYATAKE ${ }^{7,8}$, NAOMICHI MATSUMOTO ${ }^{7}$, \\ YONEHIRO KANEMURA $^{9,10}$ and TOMOKO HASHIMOTO-TAMAOKI ${ }^{2}$
}

\author{
Departments of ${ }^{1}$ Pediatrics, ${ }^{2}$ Genetic Medicine, ${ }^{3}$ Pediatric Neurosurgery, ${ }^{4}$ Pediatric Surgery, ${ }^{5}$ Pathology \\ and ${ }^{6}$ Pediatric Neuroradiology, Takatsuki General Hospital, Takatsuki, Osaka 569-1192; ${ }^{7}$ Department of Human Genetics, \\ Yokohama City University Graduate School of Medicine; ${ }^{8}$ Clinical Genetics Department, Yokohama City \\ University Hospital, Yokohama 236-0004; ${ }^{9}$ Department of Neurosurgery; ${ }^{10}$ Department of Biomedical Research \\ and Innovation, Institute for Clinical Research, National Hospital Organization \\ Osaka National Hospital, Osaka 540-0006, Japan
}

Received June 3, 2019; Accepted December 18, 2019

DOI: $10.3892 / \mathrm{mco} .2020 .1988$

\begin{abstract}
A heterozygous loss-of-function mutation of the PTEN gene, one of the tumor suppressor genes, causes a wide variety of disorders, ranging from macrocephaly/autism syndrome to PTEN hamartoma tumor syndrome, including Cowden disease that causes thyroid and breast cancer mainly in the adolescence and young adult generation. An 8-month-old male infant with simple macrocephaly developed a café-au-lait spot and two subcutaneous tumors at the age of 1 year. One of the tumors developed rapidly was resected at the age of 1 year and 9 months and identified as benign lipoma. From the age of 2 years, the patient often threw a tantrum. At the age of 2 years and 9 months, a pathogenic germline mutation was identified in the PTEN gene (NM_000314.7), c.195C>A, p.Y65* in the form of a heterozygous germline variant. Developmental delay was noted but no tumors were found in the thyroid gland and breasts. Immunohistochemistry for PTEN in the resected lipoma demonstrated that the PTEN expression pattern was similar to that in a subcutaneous adipose tissue from a normal subject, suggesting that two-hit was not likely involved in the rapid growth of this lipoma. At the age of 5 years, the patient was diagnosed with autism spectrum disorders with moderate developmental delay. A long-term follow-up is underway to examine developmental changes in psychomotor disorders and possible tumor formation.
\end{abstract}

Correspondence to: Dr Yuka Yotsumoto, Department of Pediatrics, Takatsuki General Hospital, 1-3-13 Kosobe, Takatsuki, Osaka 569-1192, Japan

E-mail: yukana@ajk.takatsuki-hp.or.jp

Key words: macrocephaly, lipoma, PTEN, PTEN hamartoma tumor syndrome, Cowden syndrome, autism spectrum disorder

\section{Introduction}

The phosphatase and tensin homolog (PTEN) gene is one of the tumor suppressor genes (1) located in chromosome 10q23.31, encoding 403 amino acids of 47166 Da protein. Loss of heterozygosity and deletion of this gene was first reported in glioblastomas, and later in several malignant tumors (2). PTEN germline mutations cause a wide variety of phenotypic diseases, such as macrocephaly/autism syndrome (OMIM \#605309) usually noticed in infants and PTEN hamartoma tumor syndrome (PHTS, OMIM \#601728). PHTS includes Cowden syndrome (CS, OMIM\#158350) and Bannayan-Riley-Ruvalcaba syndrome (BRRS, OMIM\#153480) (3).

Macrocephaly/autism syndrome is an autosomal dominant disorder characterized by increased head circumference, abnormal facial features, and delayed psychomotor development resulting in autistic behavior or mental retardation (4). Varga et al (5) reported that PTEN mutations were detected in 5 of $60(8.3 \%)$ patients with autism spectrum disorder (ASD) and 6 of $49(12.2 \%)$ patients with developmental delay and macrocephaly without ASD.

CS is a multiple hamartoma syndrome with a high risk for benign and malignant tumors of the thyroid, breast, and endometrium in young adults and adults. Arteriovenous malformation, multiple lipomas, and other soft-tissue tumors are also reported $(3,6)$. Affected individuals usually develop macrocephaly, trichilemmomas, and papillomatous papules by late 20s. On the other hand, BRRS is a congenital disorder characterized by macrocephaly, intestinal hamartomatous polyposis, lipomas, and pigmented macules of the glans penis (3). For PHTS patients, 2019.2 NCCN guideline (7) recommends that tumor follow-up involves annual physical examination and thyroid ultrasound, with colonoscopy every 5 years beginning at age 35 or earlier based on family colon cancer history and kidney ultrasound every $1-2$ years starting at age 40 . 
We found a de novo PTEN germline mutation in a male infant with macrocephaly and lipomas by using NGS analysis. A rapidly growing lipoma was resected and examined for PTEN by immunostaining, since there have been few reports on PTEN inactivation, two hits or one hit, in tumors in PHTS patients.

\section{Case report}

Patient. Male infant was born after 37 weeks gestation with $4,078 \mathrm{~g}(+2.7 \mathrm{SD})$ in weight, $52 \mathrm{~cm}(+1.4 \mathrm{SD})$ in height and $36 \mathrm{~cm}(+1.9 \mathrm{SD})$ in head circumference.

Family history: No physical abnormalities are apparent with the father, 37 years old, the mother, 33 years old and a sister, 3 years old.

Pregnancy history: Pregnancy progressed uneventfully. The delivery was through the vagina after induction.

Postnatal progress: No special findings in one- and four-month postnatal examinations. The infant showed roll-over at 6 months old, neck stabilization at 7 months old, and independent gait at 1 year and 5 months. He exhibited obsession and temper tantrum frequently after 2 years of age. Macrocephaly was pointed out when he was taken to a hospital for treatment of bronchitis at the age of 8 months. His height was then $70 \mathrm{~cm}(+2.8$ SD), weight $8,845 \mathrm{~g}(+0.2 \mathrm{SD})$ and head circumference $48.5 \mathrm{~cm}$ (+2.8 SD). Brain MRI showed no abnormal signals in cerebral parenchyma (data not shown), indicating that his macrocephaly was a simple one. To elucidate the cause of macrocephaly, genetic testing was performed at the age of 1 year and 9 months under the informed consents of the parents.

At the age of one-year, two elastic soft subcutaneous tumors of $1-2 \mathrm{~cm}$ in diameter appeared in the abdomen and in the right side of the back. A café-au-lait spot of $2 \mathrm{~cm}$ in diameter was also found on the left side of the back. At the age of 1 year and 9 months, one tumor in the abdomen rapidly enlarged to $6 \times 5 \mathrm{~cm}$ (Fig. 1A) and was surgically removed. The removed tumor was soft and yellowish and macroscopically diagnosed as a lipoma.

At the age of 2 years and 9 months, the results of genetic testing were reported, and genetic counseling was performed. At this time, his height was $92 \mathrm{~cm}(+0.2 \mathrm{SD})$, weight $16 \mathrm{~kg}$ (+2.1 SD), and head circumference $55 \mathrm{~cm}(+3.7 \mathrm{SD})$. He showed a broad and projected forehead, a flat nasal root and low-set deformed auricles. A café-au-lait spot of $2 \times 2.5 \mathrm{~cm}$ in size was present on the left back and subcutaneous tumors of $2 \times 2 \mathrm{~cm}$ in the right back (Fig. 1B) and in the sole (not shown). Developmental test by Kyoto Scale of Psychological Development 2001 (8) showed 64 scores in total developmental quotient (100 as an average), indicating that he had moderate developmental delay.

At the age of 3 years, follow-up brain MRI showed no abnormality in the cerebral white matter (Fig. 1C and D), except for the hypertrophied corpus callosum (Fig. 1E) and enlargement of the perivascular space (Fig. 1F), of which findings were consistent with simple macrocephaly.

At the age of 5 years, subcutaneous tumors in the back and the sole remained the same in size, and no newly developed tumors and café-au-lait spots were detected. He could not communicate normally and was diagnosed as ASD with moderate developmental delay.
Chromosomal analysis. Using peripheral blood, G-banding was performed.

Whole-exome sequencing and Sanger sequencing. DNA was extracted from peripheral blood of the patient and the parents and Whole exome sequencing was performed as previously described (9). Regions suspected of containing pathological mutations were amplified by PCR and subjected to Sanger analysis $\left(\mathrm{HGMD}^{\mathrm{R}}\right.$ Professional 2016.1).

Pathologic examination. The surgical specimen was fixed in formalin and embedded in a paraffin block. Sections cut from the block were stained with hematoxylin-eosin and with an immunoperoxidase method using anti-PTEN antibody (Dako/Agilent Technologies, Santa Clara, CA). Stained sections were examined under a light microscope. As a control, a subcutaneous fat containing skin sample obtained from a one-year-old male infant without CS were used anonymously.

Chromosomal analysis. Chromosomal analysis showed a normal karyotype.

Mutation of the PTEN gene. In exon 3 of the PTEN (NM_000314.7), c.195C >A, p.Y65* was found as a heterozygous germline variant in the patient. This mutation is considered as pathogenic, since the same mutation has been reported in one young adult female with macrocephaly/autism syndrome and one adult female with CS $(10,11)$ (referred HGMD ${ }^{\mathrm{R}}$ Professional 2019.1). The predicting truncated PTEN protein with deletion of most of the C-terminal region is likely unstable leading to haploinsufficiency. This mutation is sporadic, since his parents did not carry the mutation. Based on these results, we diagnosed this patient with PTEN hamartoma tumor syndrome (PHTS). As this mutation was reported in a CS case, we performed ultrasound analysis of the thyroid and visual and palpitation inspection of breasts of the patient at 2 years and 10 months. No abnormalities were found in both tissues. Endoscopic examination of gastrointestinal tract was not performed because of his young age.

Pathologic findings of the subcutaneous tumor. The surgical specimen had a lobulated macroscopic appearance and was encapsulated with delicate fibrous veil (Fig. 2A). Histologically, it consisted of mature adipocytes, sparse blood vessels and thin collagen bundles (Fig. 2B), and the diagnosis of lipoma was confirmed. Immunohistochemically, PTEN expression was observed in vessels in the control sample, as was expected (Fig. 2C and D). A few subcutaneous adipocytes were also stained. Similarly, in the lipoma tissue, vessels and a small number of neoplastic adipocytes were PTEN-positive (Fig. 2E and F). No obvious differences in PTEN expression, its distribution pattern and intensity, were detected between the lipoma tissue and the control tissue. Fig. 3 shows the position of the mutation in the PTEN protein (12). Anti-PTEN antibody binds to a C-terminal region (13). It is not possible to bind to the truncated protein due to the nonsense mutation in this patient (Fig. 3).

\section{Discussion}

We found a PTEN mutation by NGS analysis in a male infant with macrocephaly. Brain MRI examination showed 

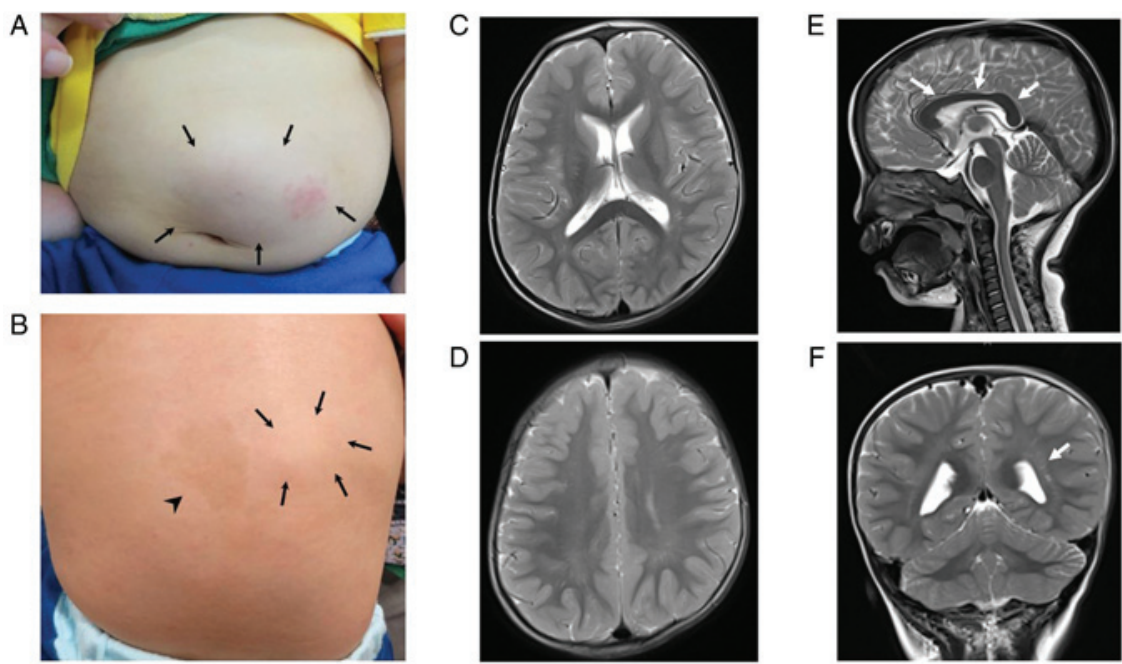

Figure 1. Skin legions and brain MRI of the patient. (A) Appearances on the upper region of the abdomen at the age of 1 year and 9 months. Arrows indicate soft and elastic mass. (B) Appearances on the back at the age of 2 years and 9 months. Arrows indicate a $2 \times 2 \mathrm{~cm}$ soft mass in the right side of the back, and an arrowhead indicates a $2 \times 2.5 \mathrm{~cm}$ café-au-lait spot on the left side of the back. (C-F) Brain MRI at the age of 3 years. (C) T2 waited axial view. (D) T2 waited axial view upper level than (C). (E) T2 waited sagittal view. Arrows indicate the large corpus callosum, pointing to macrocephaly. (F) T2 waited coronal view. A white arrow indicates the enlarged perivascular spaces with cerebrospinal fluid isointense signals were observed.

A

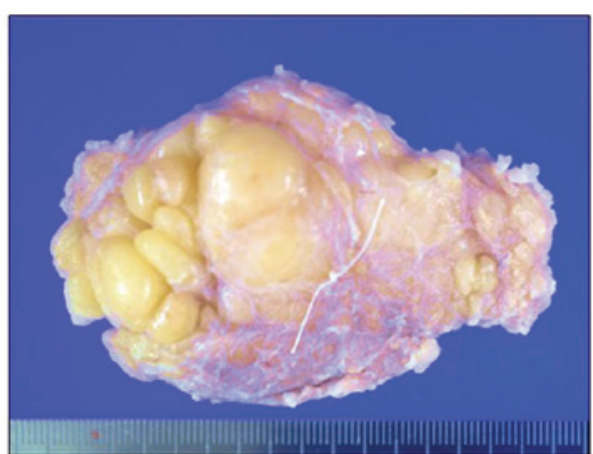

B

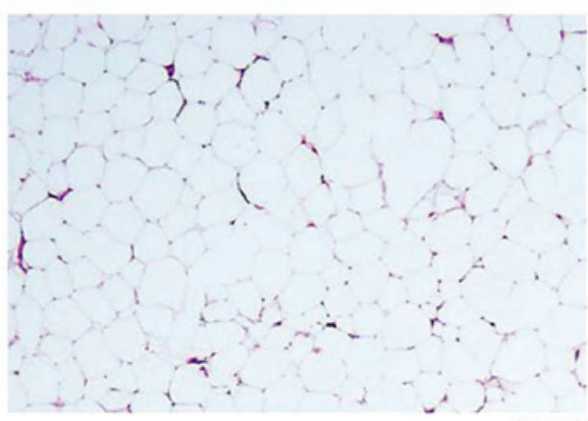

C

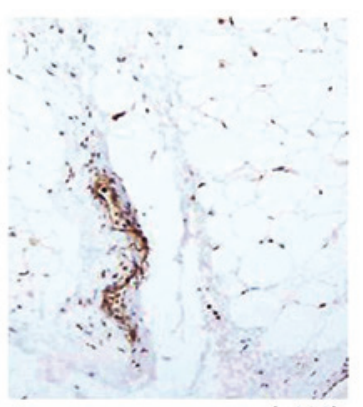

$(\times 100)$

D

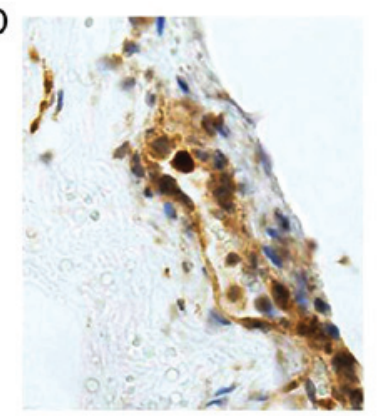

$E$

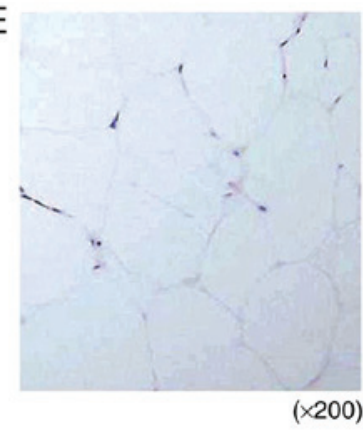

$\mathrm{F}$

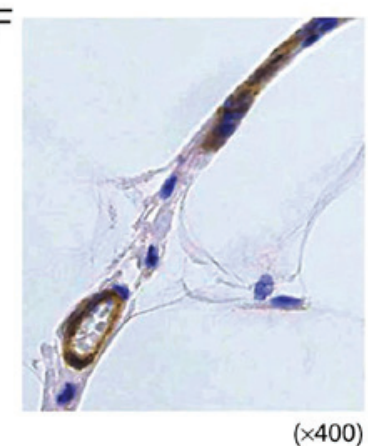

Figure 2. Pathologic findings of the surgical specimen. (A) Lobulated yellowish tumor encapsulated with delicate fibrous veil. (B) Histologically, the tumor consisted of mature adipocytes, sparse blood vessels and thin collagen bundles. Hematoxylin-eosin stain. Original magnification, x100. (C and D) A control tissue section stained with anti-PTEN antibody. PTEN immunoreactivity was observed in vessels and a few adipocytes. Original magnification, (C) x100 and (D) $x$ 400. (E and F) Tumor tissue section stained with anti-PTEN antibody. As seen in the control tissue, PTEN immunoreactivity was observed in both vessels and neoplastic adipocytes. Original magnification, (E) x100 and (F) x400.

simple macrocephaly consistent with PTEN macrocephaly/autism syndrome reported by Vanderver et al (14) and Bhargava et al (15).

Table I shows 30 patients of $<3$ years of age with macrocephaly or autism spectrum in whom PTEN mutations were detected $(4,11,14-20)$. Clinical manifestations of these patients are presented in Table II. All cases showed developmental delay with 8 cases diagnosed as autism spectrum and 10 hypotonia.
Ten of 30 cases showed frontal bossing with 8 exhibiting café-au-lait spots and skin features, and 5 diagnosed with tumors and hamartomas, such as gastrointestinal polyps and cutaneous lipomas. Our case, an only in infant patient with macrocephaly/autism syndrome reported, suggests that the PTEN mutation detected is responsible for the syndrome.

All the 30 patients with macrocephaly in Table I showed no apparent genotype-phenotype correlation nor malignant 
Table I. Reported 30 patients diagnosed as having PTEN mutation at $<3$ years.

\begin{tabular}{|c|c|c|c|c|c|}
\hline Author, year & Case no. & Age & PTEN mutation & Inheritance & (Refs.) \\
\hline Vanderver et al, 2014 & 1 & $0 \mathrm{~d}$ & $\begin{array}{l}\text { partial deletion of exon } 6 \text {, } \\
\text { identified on array-CGH; } \\
\text { arr10q23.31 } \\
(89.683 .610-89.702 .204))^{*} 1\end{array}$ & de novo & (14) \\
\hline Vanderver et al, 2014 & 2 & $3 \mathrm{~m}$ & c.1120_1121dup : p.D375* & de novo & (14) \\
\hline Vanderver et al, 2014 & 3 & $5 \mathrm{~m}$ & c.A17T : p.K6I & ND & (14) \\
\hline Tan et al, 2011 and Vanderver et al, 2014 & 4 & $7 \mathrm{~m}$ & c. $253+5 \mathrm{G}>\mathrm{T}$ & de novo & $(11,14)$ \\
\hline Vanderver et al, 2014 & 5 & $7 \mathrm{~m}$ & Yes & ND & $(14)$ \\
\hline Tan et al, 2011 and Vanderver et al, 2014 & 6 & $8 \mathrm{~m}$ & c.T149C : p.I50T & de novo & $(11,14)$ \\
\hline Present study & 7 & $8 \mathrm{~m}$ & c.C195A : p.Y65* & de novo & - \\
\hline Varga et al, 2009 & 8 & $9 \mathrm{~m}$ & p.R173H & Maternal & (5) \\
\hline Varga et al, 2009 & 9 & $9 \mathrm{~m}$ & c.IVS8-2A>G & Paternal & (5) \\
\hline Vanderver et al, 2014 & 10 & $10 \mathrm{~m}$ & c.A80G : p.Y27C & de novo & (14) \\
\hline $\begin{array}{l}\text { Vanderver et al, 2014, Bhargava et al, } \\
2014 \text { and Rodríguez-Escudero et al, } 2011\end{array}$ & 11 & $10 \mathrm{~m}$ & c.G131A : p.G44D & ND & $(14,15,16)$ \\
\hline Vanderver et al, 2014 and Nelen et al, 1997 & 12 & $10 \mathrm{~m}$ & c.C388T : p.R130* & ND & $(14,17)$ \\
\hline Vanderver et al, 2014 & 13 & $10 \mathrm{~m}$ & c.C511G : p.Q171E & Familial & $(14)$ \\
\hline Vanderver et al, 2014 and Eng, 2003 & 14 & $10 \mathrm{~m}$ & c.C633G : p.C211W & Familial & $(14,18)$ \\
\hline Herman et al, 2007 and Vanderver et al, 2014 & 15 & $10 \mathrm{~m}$ & c.C1003T : p.R335* & de novo & $(4,14)$ \\
\hline Vanderver et al, 2014 & 16 & $11 \mathrm{~m}$ & c.A16G : p.K6E & ND & $(14)$ \\
\hline Vanderver et al, 2014 & 17 & $11 \mathrm{~m}$ & c.G853T : p.G285 & de novo & $(14)$ \\
\hline Vanderver et al, 2014 & 18 & $12 \mathrm{~m}$ & c. A320G : p.D107G & ND & (14) \\
\hline Vanderver et al, 2014 & 19 & $1 \mathrm{y} 3 \mathrm{~m}$ & c.C138G : p.Y46* & ND & (14) \\
\hline Herman et al, 2007 and Varga et al, 2009 & 20 & $1 \mathrm{y} 4 \mathrm{~m}$ & c.520insT & de novo & $(4,5)$ \\
\hline Tan et al, 2011 and Vanderver et al, 2014 & 21 & $1 \mathrm{y} 6 \mathrm{~m}$ & c.A45T : p.R15S & de novo & $(11,14)$ \\
\hline Hansen-Kiss et al, 2017 & 22 & $1 \mathrm{y} 6 \mathrm{~m}$ & c.G1004A : p.R335Q & Paternal & $(19)$ \\
\hline Varga et al, 2009 & 23 & $1 \mathrm{y} 8 \mathrm{~m}$ & p.T202I & de novo & (5) \\
\hline Vanderver et al, 2014 and Eng, 2003 & 24 & $2 y$ & c.T959G : p.L320* & ND & $(14,18)$ \\
\hline Hansen-Kiss et al, 2017 & 25 & $2 y$ & c.607_608delAT : p.L230* & Maternal & $(19)$ \\
\hline Hansen-Kiss et al, 2017 & 26 & $2 y$ & c.A667T : p.K223* & $\mathrm{ND}$ & (19) \\
\hline Varga et al, 2009 & 27 & $2 y 3 m$ & p.G44D & ND & $(5)$ \\
\hline Butler et al, 2005 & 28 & $2 \mathrm{y} 6 \mathrm{~m}$ & p.F241S & ND & (20) \\
\hline Bhargava et al, 2014 & 29 & $2 \mathrm{y} 7 \mathrm{~m}$ & No protein & ND & (15) \\
\hline Bhargava et al, 2014 & 30 & $2 \mathrm{y} 8 \mathrm{~m}$ & No protein & ND & (15) \\
\hline
\end{tabular}

ND, not determined; d, days; m, months; y, years.

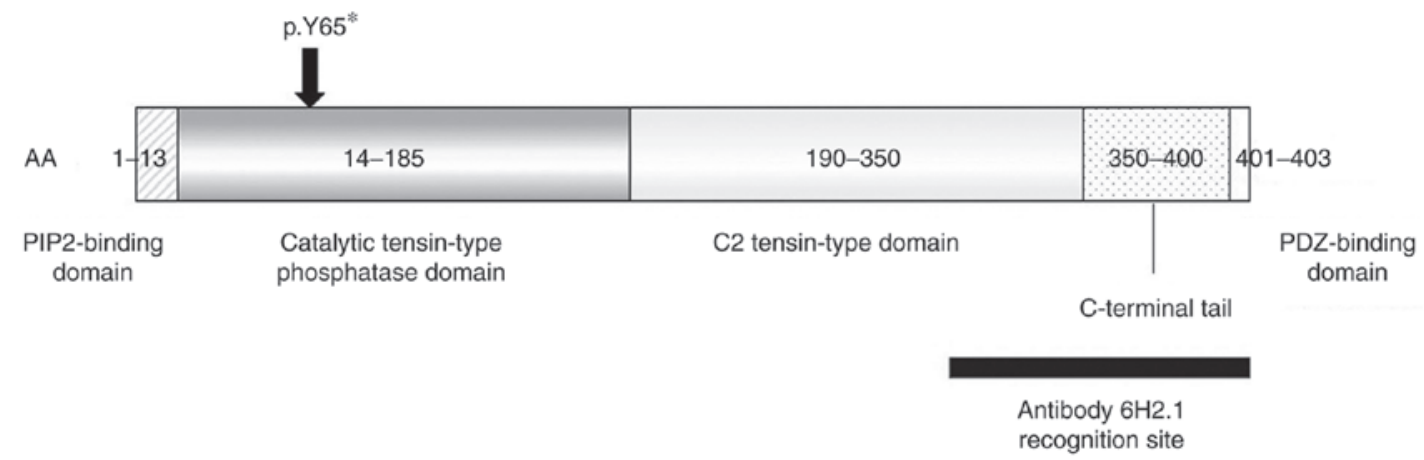

Figure 3. PTEN protein. p.Y65* is the position of the mutation in the PTEN protein. PIP2-binding domain (aa 1-13), a catalytic tensin-type phosphatase domain (aa 14-185), a C2 tensin-type domain, which binds phospholipids (aa 190-350), C-terminal tail, the carboxy-terminal tail of the protein (aa 350-400), and a PDZ-binding domain (aa 401-403) are shown (20). AB 6H2.1; Anti-PTEN antibody binds to C-terminal 100AA (21). Anti-PTEN does not bind to the patients protein due to truncation of the binding site. PIP2, phosphatidylinositol 4,5-bisphosphate. 
Table II. Clinical characteristics of 30 patients diagnosed as having PTEN mutation at <3 years old.

\begin{tabular}{|c|c|c|c|c|c|c|c|c|c|c|}
\hline \multirow{2}{*}{$\begin{array}{l}\text { Case } \\
\text { no. }\end{array}$} & \multirow[b]{2}{*}{ Age } & \multirow[b]{2}{*}{ Sex } & \multicolumn{2}{|l|}{ Growth } & \multicolumn{3}{|c|}{$\begin{array}{l}\text { Neurological } \\
\text { findings }\end{array}$} & \multicolumn{3}{|c|}{ Physical features } \\
\hline & & & $\mathrm{MC}$ & MS & MR & AS & $\begin{array}{l}\text { Hypo- } \\
\text { tonia }\end{array}$ & $\begin{array}{l}\text { Facial } \\
\text { features }\end{array}$ & Nevus and hamartoma/tumor & Others \\
\hline 1 & $0 d$ & M & + & + & $+^{\mathrm{a}}$ & & & $+^{\mathrm{i}}$ & & $\begin{array}{l}\text { Postaxial } \\
\text { polydactyly }\end{array}$ \\
\hline 2 & $3 \mathrm{~m}$ & $\mathrm{~F}$ & + & & $+^{\mathrm{b}}$ & & + & & & \\
\hline 3 & $5 \mathrm{~m}$ & M & + & & + & $+^{\mathrm{e}}$ & + & $+^{\mathrm{i}}$ & $\begin{array}{l}\text { Pigmented speckled macules } \\
\text { of the glans penis }\end{array}$ & \\
\hline 4 & $7 \mathrm{~m}$ & $\mathrm{~F}$ & + & & + & & + & $t^{\mathrm{i}}$ & & \\
\hline 5 & $7 \mathrm{~m}$ & M & + & & + & & & & $\begin{array}{l}\text { Café-au-lait spot, thyroid, } \\
\text { nodules testicular hamartomas, } \\
\text { rectal and gastric polyps }\end{array}$ & \\
\hline 6 & $8 \mathrm{~m}$ & M & + & + & + & & & & & \\
\hline 7 & $8 \mathrm{~m}$ & M & $+(2.8 \mathrm{SD})$ & + & + & $+^{\mathrm{f}}$ & & & $\begin{array}{l}\text { Café-au-lait spot, subcutaneous } \\
\text { lipomas }\end{array}$ & \\
\hline 8 & $9 \mathrm{~m}$ & M & $+(4.4 \mathrm{SD})$ & & + & & & & & \\
\hline 9 & $9 \mathrm{~m}$ & M & $+(3.5 \mathrm{SD})$ & & + & & & $+^{j}$ & & \\
\hline 10 & $10 \mathrm{~m}$ & $\mathrm{~F}$ & + & & + & & + & & & $\begin{array}{l}\text { Abnormal EEG } \\
\text { but no seizures }\end{array}$ \\
\hline 11 & $10 \mathrm{~m}$ & M & + & & $+^{\mathrm{c}}$ & & & $t^{\mathrm{i}}$ & & \\
\hline 12 & $10 \mathrm{~m}$ & $\mathrm{~F}$ & + & & + & & + & $+^{\mathrm{k}}$ & & \\
\hline 13 & $10 \mathrm{~m}$ & $\mathrm{~F}$ & + & & + & + & + & $t^{\mathrm{i}}$ & & Left cataract \\
\hline 14 & $10 \mathrm{~m}$ & M & + & & + & $t^{g}$ & & & & \\
\hline 15 & $10 \mathrm{~m}$ & $\mathrm{~F}$ & + & & + & & & $+^{\mathrm{i}}$ & $\begin{array}{l}\text { Abdomen and axillar } \\
\text { trichilemmomas, subcutaneous } \\
\text { lipomas }\end{array}$ & Split uvula \\
\hline 16 & $11 \mathrm{~m}$ & $\mathrm{~F}$ & + & & + & & + & & & \\
\hline 17 & $11 \mathrm{~m}$ & $\mathrm{~F}$ & + & & + & & + & $+^{\mathrm{i}}$ & Mucosal neuroma & \\
\hline 18 & $1 \mathrm{~m}$ & M & + & & + & & + & $+^{\mathrm{k}}$ & & \\
\hline 19 & $1 \mathrm{y} 3 \mathrm{~m}$ & $\mathrm{~F}$ & + & & + & & & & & \\
\hline 20 & $1 \mathrm{y} 4 \mathrm{~m}$ & $\mathrm{~F}$ & $+(5.8 \mathrm{SD})$ & & + & $t^{\mathrm{h}}$ & & & & \\
\hline 21 & $1 \mathrm{y} 6 \mathrm{~m}$ & M & + & & + & & & & & \\
\hline 22 & $1 \mathrm{y} 6 \mathrm{~m}$ & $\mathrm{~F}$ & $+(2.6 \mathrm{SD})$ & & + & & & & Dermalogical features, BRRS & \\
\hline 23 & $1 \mathrm{y} 8 \mathrm{~m}$ & M & $+(6.5 \mathrm{SD})$ & & + & & & & & \\
\hline 24 & $2 y$ & M & + & & + & + & + & $+^{1}$ & & \\
\hline 25 & $2 y$ & $\mathrm{~F}$ & $+(6.5 \mathrm{SD})$ & & + & & & & BRRS & \\
\hline 26 & $2 \mathrm{y}$ & $\mathrm{F}$ & $+(4.7 \mathrm{SD})$ & & + & & & & & \\
\hline 27 & $2 \mathrm{y} 3 \mathrm{~m}$ & $\mathrm{~F}$ & $+(5.0 \mathrm{SD})$ & & + & & & & $\begin{array}{l}\text { Large café-au-lait spots on } \\
\text { chest and abdomen }\end{array}$ & Bilateral hernia \\
\hline 28 & $2 \mathrm{y} 6 \mathrm{~m}$ & M & $+(4.5 \mathrm{SD})$ & & + & + & & & Freckles on the glans penis & \\
\hline 29 & $2 \mathrm{y} 7 \mathrm{~m}$ & M & + & & + & & & & $\begin{array}{l}\text { moles, thyroid nodules, } \\
\text { intestinal polyps }\end{array}$ & \\
\hline 30 & $2 \mathrm{y} 8 \mathrm{~m}$ & M & + & & $+^{\mathrm{d}}$ & + & & & & \\
\hline
\end{tabular}

${ }^{a}$ Mild motor only at $2.5 \mathrm{y}$; ${ }^{\mathrm{d}}$ diagnosed at $2 \mathrm{y} 8 \mathrm{~m} ;{ }^{\mathrm{c}}$ mild motor delay only; ${ }^{\mathrm{d}}$ motor speech disorder; ${ }^{\mathrm{e}}$ diagnosed at $5 \mathrm{y} ;{ }^{\mathrm{f}}$ diagnosed at $3 \mathrm{y} 0 \mathrm{~m} ;{ }^{\mathrm{g}}$ diagnosed

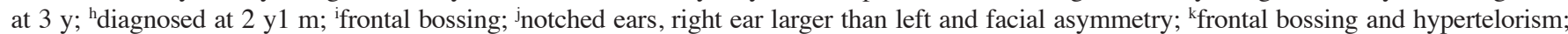
'frontal bossing, depressed nasal bridge, bulbous nose, and smooth philtrum. MC, macrocephaly (head circumference >2 SD); MS, macrosomia; MR, mental retardation/developmental delay; AS, autism spectrum; BRRS, Bannayan-Riley-Ruvalcaba syndrome; d, days; m, months; y, years.

tumors that are frequently observed in patients with CS. The risk of developing malignant tumors in later years is not clear, without follow-up data.
Tan et al (21) reported lifetime cancer risks of individuals with PTEN germline mutation listing a variety of cancers (breast, thyroid, endometrial, colorectal, renal cell, 
and melanoma) found in a cohort of 368 children and adults aged 0.4-83 years (median age; 39 years). The earliest age of cancer onset reported was 3 years for melanoma. In this paper, no follow-up analysis from childhood to adulthood was reported. Consequently, it is not clear as to how many infant macrocephaly cases with PTEN mutation developed to CS in adulthood. Smpokou et al (22) reported that, in the case of a 7-year-old patient with a thyroid cancer, clinical description would allow better formulation of clinical guidelines in children with PHTS. For infant patients with PTEN mutation, pediatricians have tendency to focus attention on macrocephaly, developmental delay or autism. It is therefore important to conduct follow-up assessment for both developmental problem and cancer incidence, and carry out lifelong and total medical management.

On this basis, we conducted thyroid ultrasonography of our patient at the age of 2 years and 10 months, 4 years and 5 years of age and found no abnormality. Regarding gastrointestinal tract hamartomas, we did not perform endoscopic examination, since there have been no reports on the onset in childhood. We examined breasts only by inspection and palpation since the possibility of breast cancer was considered to be lower for male infant patients than female (23).

Lipomas and a café-au-lait spot on the skin were also found in our case. Our immunohistochemical examination revealed that lipoma tissue and the skin tissue obtained from a control subject showed very similar PTEN expression. No obvious differences in PTEN expression were detected among them, suggesting that two-hit in the PTEN gene by loss of heterozygosity was unlikely even in the rapidly growing lipoma. A previous report shows that loss of heterozygosity of markers in endometrial cancer, glioblastoma, and breast cancer (13). In our lipoma case, we are unable to do the immunohistochemical evaluation clearly.

To relieve psychosocial anxiety for PHTS patients and their parents with respect to cancer predisposition and developmental problems, genetic counseling is of need. Genetic counseling is also of use for family members who may feel at risk. Taken together, long-term follow-up plans for soft-tissue tumors, thyroid cancer, breast cancer and GI-hamartomas, as well as psychosocial problems are indispensable.

\section{Acknowledgements}

The authors would like to thank Dr Ai Takada (Department of Human Genetics, Yokohama City University Graduate School of Medicine, Yokohama, Japan) and Ms Yasuko Takahata (Department of Genetic Medicine, Takatsuki General Hospital, Osaka, Japan) for their help in this study and ethical board tasks.

\section{Funding}

The present study was supported grants by AMED (grant nos. JP18ek0109280, JP18dm0107090, JP18ek0109301, JP18ek0109348 and JP18kk020500), JSPS KAKENHI (grant nos. JP17H01539 and JP17K10080; to NM) and Kawano Masanori Memorial Public Interest Incorporated Foundation for Promotion of Pediatrics (to SM).

\section{Availability of data and materials}

The datasets used and/or analyzed during the current study are available from the corresponding author on reasonable request.

\section{Authors' contributions}

YY wrote the manuscript. YY, AH and JT acquired the patient data and contributed clinical advice. YI pathologically diagnosed the patient and wrote the manuscript. HU evaluated the images. SM, NM and YK performed genetic analysis. THT performed genetic counseling and revised the manuscript. All authors read and approved the final manuscript.

\section{Ethics approval and consent to participate}

Gene analysis was conducted with approval of Ethical Review Board of Takatsuki General Hospital (IRB no. 2012-8). Histological analysis was conducted after obtaining approval of Ethical Review Board of Takatsuki General Hospital (IRB No. 2017-25).

\section{Patient consent for publication}

Informed consent was obtained from a parent of the patient for the publication of the case details and any associated images since the patient was a child.

\section{Competing interests}

The authors declare that they have no competing interests.

\section{References}

1. Li J, Yen C, Liaw D, Podsypanina K, Bose S, Wang SI, Puc J, Miliaresis C, Rodgers L, McCombie R, et al: PTEN, a putative protein tyrosine phosphatase gene mutated in human brain, breast, and prostate cancer. Science 275: 1943-1947, 1997.

2. Teng DH, Hu R, Lin H, Davis T, Iliev D, Frye C, Swedlund B, Hansen KL, Vinson VL, Gumpper KL, et al: MMAC1/PTEN mutations in primary tumor specimens and tumor cell lines. Cancer Res 57: 5221-5225, 1997.

3. Eng C: PTEN hamartoma tumor syndrome. Gene reviews https://www.ncbi.nlm.nih.gov/books/NBK1488/ Accessed 1 March 2017.

4. Herman GE, Butter E, Enrile B, Pastore M, Prior TW and Sommer A: Increasing knowledge of PTEN germline mutations: Two additional patients with autism and macrocephaly. Am J Med Genet A 143A: 589-593, 2007.

5. Varga EA, Pastore M, Prior T, Herman GE and McBride KL: The prevalence of PTEN mutations in a clinical pediatric cohort with autism spectrum disorders, developmental delay, and macrocephaly. Genet Med 11: 111-117, 2009.

6. Kurek KC, Howard E, Tennant LB, Upton J, Alomari AI, Burrows PE, Chalache K, Harris DJ, Trenor CC III, Eng C, et al: PTEN hamartoma of soft tissue: A distinctive lesion in PTEN syndromes. Am J Surg Pathol 36: 671-87, 2012.

7. NCCN Clinical Practice Guidelines in OncologyVersion 3.2019 Cowden syndrome/PHTS. NCCN Guidelines®: https://www. nccn.org/professionals/physician_gls/pdf/genetics_screening. pdf. Accessed 8 May 2019.

8. Society for the Kyoto scale of psychological development test. Shinpan K Shiki Hattatsu Kensahou 2001 Nenban (The Kyoto Scale of Psychological Development Test 2001). Kyoto, Japan: Nakanishiya Shuppan, 2008.

9. Iwama K, Osaka H, Ikeda T, Mitsuhashi S, Miyatake S, Takata A, Miyake N, Ito S, Mizuguchi T and Matsumoto N: A novel SLC9A1 mutation causes cerebellar ataxia. J Hum Genet 63: 1049-1054, 2018 
10. D'Gama AM, Pochareddy S, Li M, Jamuar SS, Reiff RE, Lam AN, Sestan N and Walsh CA: Targeted DNA sequencing from autism spectrum disorder brains implicates multiple genetic mechanisms. Neuron 88: 910-917, 2015.

11. Tan MH, Mester J, Peterson C, Yang Y, Chen JL, Rybicki LA, Milas K, Pederson H, Remzi B, Orloff MS and Eng C: A clinical scoring system for selection of patients for PTEN mutation testing is proposed on the basis of a prospective study of 3042 probands. Am J Hum Genet 88: 42-56, 2011.

12. Bermúdez Brito M, Goulielmaki E and Papakonstanti EA: Focus on PTEN regulation. Front Oncol 5: 166, 2015.

13. Perren A, Weng LP, Boag AH, Ziebold U, Thakore K, Dahia PL, Komminoth P, Lees JA, Mulligan LM, Mutter GL and Eng C: Immunohistochemical evidence of loss of PTEN expression in primary ductal adenocarcinomas of the breast. Am J Pathol 155: 1253-1260, 1999.

14. Vanderver A, Tonduti D, Kahn I, Schmidt J, Medne L, Vento J, Chapman KA, Lanpher B, Pearl P, Gropman A, et al: Characteristic brain magnetic resonance imaging pattern in patients with macrocephaly and PTEN mutations. Am J Med Genet A 164A: 627-633, 2014.

15. Bhargava R, Au Yong KJ and Leonard N: Bannayan-RileyRuvalcaba syndrome: MRI neuroimaging features in a series of 7 patients. Am J Neuroradiol 35: 402-406, 2014

16. Rodríguez-Escudero I, Oliver MD, Andrés-Pons A, Molina M, Cid VJ and Pulido R: A comprehensive functional analysis of PTEN mutations: Implications in tumor- and autism-related syndromes. Hum Mol Genet 20: 4132-4142, 2011.
17. Nelen MR, van Staveren WC, Peeters EA, Hassel MB, Gorlin RJ, Hamm H, Lindboe CF, Fryns JP, Sijmons RH, Woods DG, et al: Germline mutations in the PTEN/MMAC1 gene in patients with Cowden disease. Hum Mol Genet 6: 1383-1387, 1997.

18. Eng C: PTEN: One gene, many syndromes. Hum Mutat 22 183-198, 2003

19. Hansen-Kiss E, Beikampen S, Adler B, Frazier T, Prior T, Erdman S, Eng C and Herman G: A retrospective chart review of the features of PTEN hamartoma tumour syndrome in children. J Med Genet 54: 471-478, 2017.

20. Butler MG, Dasouki MJ, Zhou XP, Talebizadeh Z, Brown M, Takahashi TN, Miles JH, Wang CH, Stratton R, Pilarski R and Eng C: Subset of individuals with autism spectrum disorders and extreme macrocephaly associated with germline PTEN tumour suppressor gene mutations. J Med Genet 42: 318-321, 2005.

21. Tan MH, Mester JL, Ngeow J, Rybicki LA, Orloff MS and Eng C: Lifetime cancer risks in individuals with germline PTEN mutations. Clin Cancer Res 18: 400-407, 2012.

22. Smpokou P, Fox VL and Tan WH: PTEN hamartoma tumour syndrome: Early tumour development in children. Arch Dis Child 100: 34-37, 2015.

23. Pilarski R: PTEN hamartoma tumor syndrome: A clinical overview. Cancers (Basel) 11: E844, 2019.

This work is licensed under a Creative Commons

Attribution-NonCommercial-NoDerivatives 4.0

International (CC BY-NC-ND 4.0) License. 